\title{
PRESSURE ENHANCEMENT OF THE DEPRESSANT EFFECT OF HALOTHANE ON CILIAL BEAT
}

\author{
W.D.B. Pope, A.J. Jones, M.J. HALSEy, AND J.F. NunN
}

IT HAS LONG BEEN KNOWN that high pressure "antagonizes" general anaesthesia produced by most inhalational agents in newts ${ }^{1}$ and mammals. ${ }^{2}$ These phenomena have led to the formulation of the critical volume hypothesis of general anaesthesia ${ }^{3}$ which is associated with a fixed expansion of a hydrophobic site. However, the quantitative relationships are not completely consistent with the site, or sites, having unique physical properties. There is also increasing evidence that anaesthetics act at many different molecular sites, some of which result only in the production of side effects, such as myocardial depression or inhibition of cell division. The molecular sites of action are in all cases unknown, but study of the effects of pressure offers the possibility of determining whether the action is in accord with the critical volume hypothesis. If there is no pressure reversal of the effects of an anaesthetic, it would seem unlikely that the mode of action depends upon the expansion of a hydrophobic receptor site.

Depression of cilial beat has long been known to be a general effect of anaesthetics and doseresponse curves have recently been prepared for the effect of five inhalational anaesthetics on the swimming speed of Tetrahymena pyriformis. ${ }^{4}$ The site of action of anaesthetics in cilial beat is unknown, and we have investigated the effects of pressure to see whether the critical volume hypothesis applies to this action.

\section{Method}

Depression of cilial beat was measured by changes in swimming speed of the ciliate proto-

W.D.B. Pope, M.D. Visiting Scientist; A.J. Jones, Senior Technician; M.J. Halsey, D. Phil., Scientific staff; J.F. Nunn, M.D., Ph.D., F.F.A.R.C.S., Head of Division. The Division of Anaesthesia, Clinical Research Centre, Watford Road, Harrow, Middlesex HAI 3 UJ, England.

Supported in part by SERF Grant, Health Sciences Center, Winnipeg.

Dr. Pope's current address is: Department of Anaesthesia, University of Manitoba, Health Sciences Centre, 700 William Ave., Winnipeg. R3E $0 Z 3$.

Reprint requests to W.D.B. Pope, M.D.

Canad. Anaesth. Soc. J., vol. 25, no. 4, July 1978 zoon Tetrahymena pyriformis using the methods previously described. ${ }^{4}$ The organism was grown in axenic culture in two per cent proteose peptone and all observations were made when the culture had proceeded to stationary growth phase. These organisms swim in a straight line until a collision occurs and the mean velocity of a group of 20 organisms was determined by filming ( 16 frames per second) and subsequently analysing the projected film, frame-by-frame. We used a Vintern Mk. $316 \mathrm{~mm}$ cine camera and a Spectro analysing projector.

\section{Pressure Chamber}

We designed and built the special pressure chamber shown in Figure 1, which can be accommodated on the stage of a Vickers 15 a microscope, using bright field illumination and a $\times 2.5$ objective. The body of the chamber was stainless steel with perspex windows at top and bottom, sealed with neoprene $\mathrm{O}$-rings. The inlet tube, fitted with a tap, permitted suspensions of Tetrahymena to be drawn into the chamber, while the outlet tube was connected to a Budenberg dead weight tester. This permitted the application of pressures up to 137 atmospheres absolute (ATA). A screw-operated plunger in the oil reservoir was used for drawing the suspension into the pressure chamber. A flexible neoprene diaphragm separated the suspension from the oil contained in the dead weight tester.

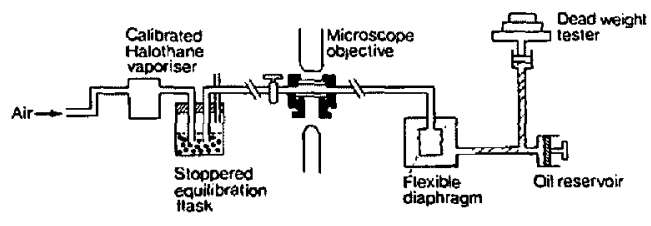

FIGURE 1 A suspension of Tetrahymena pyriformis was equilibrated with a known concentration of halothane in air. It was then drawn into the pressure chamber (shown in the centre) by manipulation of the oil reservoir (shown on the right), the suspension being separated from the oil by the flexible diaphragm. Pressure was then applied with the dead weight tester and the movement of the organisms was recorded by $\mathrm{mi}-$ crocinephotography as described in the text. 319 
Ancesthesia

Tetrahymena were exposed to a known partial pressure of halothane by bubbling halothane in air thıough a suspension in a stoppered equilibration flask for 30 minutes. Halothane was delivered from a Fluotec mark 3 vapourizer and the effluent concentration was monitored with a Riken interference refractometer. The gas flow was stopped before the "anaesthetized" suspension was drawn into the pressure chamber. It was initially maintained at atmospheric pressure and there was no recovery of swimming speed, indicating no significant loss of halothane into the materials of the pressure chamber. There were also no trapped bubbles of halothane in the chamber as observed through the microscope (magnification $\times 25$ ).

\section{Procedure}

Unanaesthetized Tetrahymena were drawn into the chamber and filmed during alternate periods at atmospheric pressure and 137 ATA, each period lasting one minute with application and removal of pressure taking less than ten seconds. After the second reduction of pressure, the pressure was again applied for a period of 15 minutes and then finally removed. An identical procedure was followed with Tetrahymena which had been equilibrated with $0.5,1.0,2.0,3.0$ and 4.0 per cent halothane.

\section{RESULTS}

Application of 137 ATA pressure to unanaesthetized Tetrahymena had no significant effect on swimming speed (Figure 2). Equilibration with halothane resulted in the expected reduction in swimming speed (Figure 3) and application of

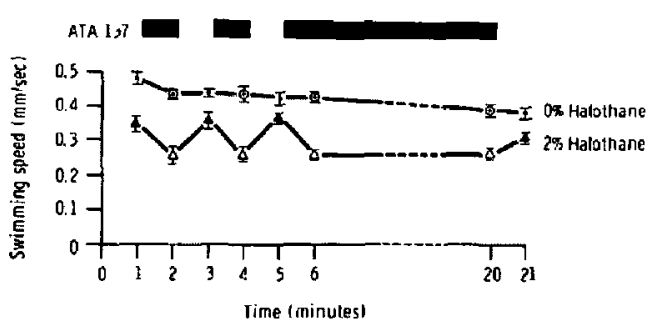

Figure 2 The effect of pressure on swimming speed of unanaesthetized and anaesthetized Tetrahymena. The blocks indicate the application of 137 atmospheres absolute. Error bars indicate mean \pm 1 s.e.m.

Symbols: * halothane 0\%; pressure 0 ATA

$\odot$ halothane $0 \%$; pressure 137 ATA

$\Delta$ halothane $2 \%$; pressure 0 ATA

$\Delta$ halothane $2 \%$; pressure 137 ATA

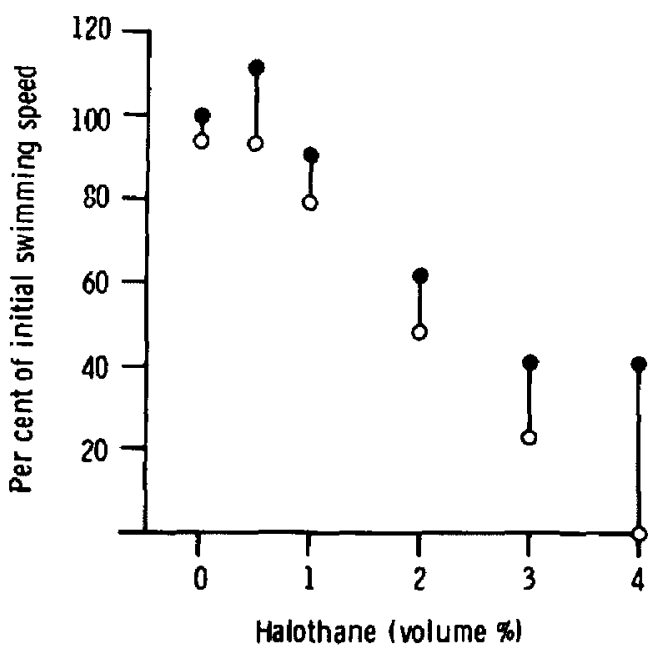

Figure 3 The closed circles show the dose/response curve for halothane on swimming speed at atmospheric pressure. The open circles indicate the enhanced effect of the same concentration of halothane at 137 atmospheres absolute.

pressure to the anaesthetized preparation resulted in a further reduction in swmming speed (Figures 2 and 3). This was instantaneous, reversible and repeatable, showing no significant changes during sustained application of pressure for 15 minutes.

Figures 3 and 4 are based on mean swimming speeds of pooled data at the end of the ist, $3 \mathrm{rd}$ and
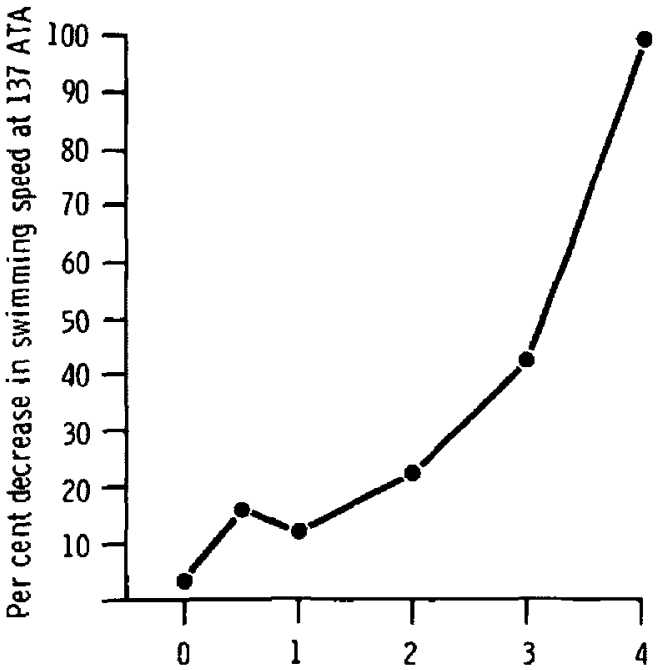

Halothane (volume \%)

Figure 4 The effect on swimming speed of increasing pressure to 137 atmospheres absolute as a function of halothane concentration with which the preparation had been equilibrated. 
5th minutes (atmospheric pressure) and also at the end of the 2 nd, 4 th and 6 th minutes (137 ATA) as indicated in Figure 2. Figure 3 shows the depression of swimming speed (as a percentage of controls, unanaesthetized at atmospheric pressure) as a function of halothane concentration from 0.5 to 4 per cent. Open circles show the further reduction in swimming speed during application of 137 ATA pressure. The percentage change in swimming speed on application of pressure was itself a function of the concentration of halothane with which the suspension had been equilibrated (Figure 4).

\section{Discussion}

High pressures of 100-200 ATA have been shown to reverse tadpole narcosis produced by a wide range of agents, including halothane. 5 Pressure-halothane interactions in mammals have not yet been investigated because the anaesthetic has a relatively slow uptake which prevents the inspired concentration being used as a reliable index of anaesthetic potency. However, other inhalational agents with faster rates of uptake (isoflurane, ${ }^{6}$ nitrous oxide, ${ }^{2}$ argon and nitrogen ${ }^{7}$ ) have been studied at high pressures using mice. The quantitative relationships between anaesthetizing partial pressures and ambient pressures are complex, but in all these cases the apparent anaesthetic potency is decreased at elevated pressures.

Until recently it appeared that pressure reversal would be a general feature of the actions of the common anaesthetics. However, the interaction of pressure and anaesthesia on other organisms or isolated systems appears to be less well defined. The early studies on the depression of bioluminescence by a wide range of both conventional and unusual narcotics demonstrated that pressure could produce either antagonistic or synergistic effects. ${ }^{8}$ More recent studies ${ }^{9}$ found that pressure enhanced the depressant effect of low doses of halothane on the division of Tetrahymena pyriformis. It was later shown that pressure enhancement could also occur with the depressant actions on excitable membranes. Several workers ${ }^{10.11}$ have reported that the depression of nerve conduction with the spin-label TEMPO was enhanced by pressure. In 1975 , Kendig and Cohen ${ }^{12}$ reported pressure enhancement of the depression by halothane of synaptic transmission in rat ganglia.

In our own study, a pressure of 137 ATA had a negligible effect on the unanaesthetized prepara- tion, in agreement with previous workers. ${ }^{13}$ We chose to study the effect of one pressure which had been demonstrated already to have significant effects on other anaesthetized model systems, but was sufficiently low to avoid the gross manifestations of the direct effects of very high pressures.

We studied a range of halothane concentrations, and the $\mathrm{ED}_{50}$ of our unpressurized preparations was 2.5 per cent. This was higher than that observed in our previous work, ${ }^{4}$ probably due to the different experimental methods and possibly to the variations in our stock culture.

Because the halothane dose-response curves at 1 ATA and 137 ATA are not parallel (Figure 3), it is not appropriate to compare statistically the $\mathrm{ED}_{50}$. However, there is clearly a significant difference at 2 per cent halothane concentration ( $\mathrm{Fi}$ gure 2) which is the approximate $\mathrm{ED}_{50}$ for the anaesthetized preparation at 137 ATA. The divergence of the two curves is consistent with the hypothesis that halothane and pressure have separate molecular sites of action in this preparation. This would appear to demarcate the narcotic effect of anaesthetics from the type of molecular interaction which is concerned in the effect on cilial beat.

\section{ACKNOWLEDGEMENTS}

We are indebted to Mrs. Jean Sturrock for supply of the culture of Tetrahymena pyriformis, and to Miss Brenda Dobson for preparation of the manuscript.

\section{SUMMARY}

In order to test the applicability of the critical volume hypothesis of anaesthetic action to the side effects of anaesthesia, we have studied the pressure-anaesthetic interactions on cilial beat. The swimming speed of Tetrahymena pyriformis was determined at one and 137 atmospheres with 0 to 4 per cent halothane. The pressure and anaesthetic effects were synergistic with the halothane dose-response curve being shifted to the left and increased in slope at the high pressure, although high pressure alone had no significant effect. These results are contrary to the predictions of the critical volume hypothesis and appear to demarcate the narcotic effect of anaesthetics from the type of molecular interaction which is concerned in the effect on cilial beat. 


\section{RÉSUMÉ}

La vitesse de nage du protozoaire flagellé tétrahymène pyriforme a été établie dans une chambre à pression. Elle diminuait de façon significative à une pression de 137 atmosphères abolues. A compter de 0.5 pour cent de concentration, l'halothane réduisait la vitesse de nage du micro-organisme et ceci de façon proportionnelle à la concentration, la vitesse étant diminuée de 50 pour cent à une concentration de 2.5 pour cent. A 137 atmosphères, les effets de l'halothane étaient plus importants, une réduction de 50 pour cent de la vitesse étant observée à une concentration de 2 pour cent. La pente de la courbe était également plus raide à pression élevée. En étudiant les effets combinés de la pression et de l'anesthésique, on a observé une synergie d'action entre les deux. Ces résultats sont contraires à ceux prédits selon l'hypothèse du volume critique et semblent éta. blir une différence entre les effets narcotiques des anesthésiques et les effets sur les battements ciliaires.

\section{REFERENCES}

1. Johnson, F.H. \& Flagler, E.A. Hydrostatic pressure reversal of narcosis in tadpoles. Science, 112: $91-92$ (1950).

2. Halsey, M.J., Eger, E.I., Kent, D.W., \& WARNE, P.J. High-pressure studies of Anesthesia. Progr. Anesthesiol. I: 353-361 (1975).
3. Lever, M.J., Miller, K.W., Paton, W.D.M., \& SMITH, E.G. Pressure reversal of anaesthesia. Nature, $231: 368-371$ (1971).

4. NunN, J.F., Sturrock, J.E., Wills, E.J., Richmond, J.E., \& MCPherson, C.K. The effect of inhalational anaesthetics on the swimming velocity of Tetrahymena Pyriformis. J. Cell Sci., 15: 537-554 (1974).

5. Halsey, M.J. \& Wardley-Smith, B. Pressure reversal of narcosis produced by anaesthetics, narcotics and tranquillizers. Nature, 257: $811-813$ (1975).

6. KeNt, D.W., Halsey, M.J., Eger, E.I., \& Kent, B. Isoflurane anesthesia and pressure antagonism in mice. Anesth. Analg. (Curr. Res.) 56: 97-101 (1977).

7. Smith, R.A., Winter, P.M., Halsey, M.J., \& EgER, E. I. Helium pressure produces a non-linear antagonism of argon or nitrogen anesthesia in mice. A.S.A. Abstracts. 217-218(1975).

8. Johnson, F.H., Eyring, H., \& Polissar, M.J. The Kinetic Basis of Molecular Biology, New York, Wiley, 286-368 (1954).

9. KirkNESS, C.M. \& MaCDONALD, A.G. Interaction between anaesthetics and hydrostatic pressure on the division of Tetrahymena Pyriformis. Exp. Cell Res., 75: 329-336 (1972).

10. Hsia, J.C., \& Bogcs, J.M. Pressure effect on the membrane action of a nerve-blocking spin label. Proc. Nat. Acad. Sci, , 70: 3179-3183 (1973).

11. Roth, S.H. Anesthesia and pressure: antagonism and enhancement. Progr. Anesthesiol. 1: 405-420 (1975).

12. Kendig, J.J. \& CohEN, E.N. Neural sites of pressure - anesthesia interactions. Progr. Anesthesiol., 1: $421-427$ (1975).

13. Kitching, J.A. Effects of high hydrostatic pressures on the activity of flagellates and ciliates. J. Exp. Biol., 34: 494-510 (1957). 